\title{
Needs perceived by people with developmental disabilities in the ageing process
}

\begin{abstract}
Background: The increase in the life expectancy in people with developmental disabilities is linked to independent living and full participation in every aspect of life.

Aims: To analyse the needs and solutions linked to barriers found by people with cerebral palsy older than 45 , their families and the professionals who help them.

Methods and procedures: A transversal sample with 104 people with cerebral Palsy was used, 34 relatives and 217 professionals who responded to a semi structured interview.

Results: The 853 answers regarding accessibility needs highlight the presence of architectonic barriers not only for the disabled person, but also for their relatives. It also highlights social barriers for care professionals. Disabled people and their relatives propose that one solution is to eliminate barriers and achieve better acceptance from society.

Conclusions: These results allow to design better care, wellbeing promotion, life quality, autonomy and full development for ageing people with developmental disabilities, which will mean bigger opportunities and smaller cost for them, their relatives and society.
\end{abstract}

Keywords: accessibility, independent life, universal design, participation, inclusion, cerebral palsy
Volume 5 Issue 2 - 2018

\author{
María Yolanda González-Alonso,' Raquel \\ Aceves $^{2}$ \\ 'University of Burgos, Spain \\ ${ }^{2}$ Federación ASPACE, Spain
}

Correspondence: María Yolanda González-Alonso, Faculty of Health Sciences, University of Burgos, Paseo Comendadores s/n, 0900 I Burgos, Spain, Tel 34638098463 ,

Email mygonzalez@ubu.es

Received: February 01, 2018 | Published: April 24, 2018

\section{What else offers this article?}

Amongst the reasons which explain the relevance of this article we can highlight the relevance of knowing and taking into account the opinions and experiences of people with developmental disabilities, even those severely affected and their families and accessibility professionals. On the other hand it has in mind the solutions which these three involved groups prioritise which in turn will be used to guide the attention and promotion of their wellbeing, quality of life, personal autonomy and full development in a stage of life so unknown such as old age.

This study tries to contribute to fulfil the rights of people with developmental disabilities who are growing old by facilitating information about their current needs. The comprehensive accessibility wants to apply a good design thinking of different citizen's situations from the beginning, opposing the old concept of barrier elimination.

\section{Introduction}

Lately life expectancy has increased considerably thanks to the success to Science in health and the support and development of resources and bigger accessibility to social inclusion and life improvements. ${ }^{1,2}$ This means that more people with developmental disabilities are reaching advance ages, which in turn it involves great challenges. It is about amplifying the health and quality of life expectancy for everyone as they get older including those with development disability, ${ }^{3-6}$ since all of them can continue to contribute actively within their abilities, either in the family environment, or with their friends or more extensively with the community. ${ }^{7}$

Disability is part of the human condition, the International
Classification of Functioning, Disability and Health, ${ }^{8}$ defines it as a generic term which includes deficiencies, limitations in activities and restrictions in participation. It includes negative aspects of interaction between people with a health problem (developmental disability) and personal and environmental factors (inaccessible buildings, transport, negative attitudes and lack of social support). ${ }^{9}$ The ICF uses a biopsychosocial focus which gives a coherent vision of the different health dimensions from a biological, individual and social perspective..$^{10}$ Disabilities are complex and the interventions to overcome the disadvantages associated are multiple, systemic and variable according to the context.

The International Convention on people with disability rights, ${ }^{8}$ and the World Report on Disability, ${ }_{11}^{11}$ gather information to improve these people's lives and safeguards human rights equality. People with developmental disabilities have the right to have an independent life and to take part in every aspect of life fully. ${ }^{12,13}$ It is to be taken into consideration the needs derived in every stage of the life cycle of disabled people in their way to old age and their families. ${ }^{14}$ To achieve this we must guarantee universal accessibility, in equal conditions to others, with regard to the environment, processes, goods, products, services, transport, information and communication technologies and social communication. ${ }^{15}$ From the European Strategy 2010-2020 a bigger visibility of disable people as citizens is demanded and it develops an antidiscrimination policy which brings up challenges for the immediate future. ${ }^{16}$

In 2002 the World Health Organization defined active ageing as a process of optimization of health, participation and safety opportunities with the aim of improving the quality of life as we age. ${ }^{17}$ In the case of people with developmental disabilities important 
steps have been given, which have enhanced these people's abilities, attempting to achieve bigger participation in every area. To age well is for everyone and any age. The research and innovation should give specific procedures for the challenges which the promotion of active ageing entails, no matter which are the condition and abilities; it should respect the diversity to start programs where the prominence stems out from the very same people in question. ${ }^{18}$ Older people with disabilities should be consulted about issues which matters to them directly, whether is either about health, education, rehabilitation or community life, as they have the right to control their life. ${ }^{19}$ Disabled people enter the ageing stage with some attitudes towards disability which could benefit them as they have had many years or nearly all their lives facing these types of situations. It is about making the results visible and spread the positive results achieved in autonomy, inclusion, quality of life and wellbeing and spreading them. ${ }^{20}$

The aim of ageing is to manage so that each person develops their potential of physical, intellectual and social wellbeing throughout their life and that they can participate in the society according to their needs, wishes and abilities. ${ }^{21}$ It considers to tackle this challenge and to know the needs perceived by people with developmental disability in the process of ageing and the solutions proposed. Not only it takes an interest in thinking of the affected people, but also it wants to know the needs of their families who support them, ${ }^{22}$ and the professionals who assist them. Getting old in a competent way is influenced by the transactions produced due to chance, biology, environment, physical and social stimuli, given that the individual is an active agent in its own ageing process. This provides a great variety of ways of getting older, human beings age in different ways according to their interaction with the socio-cultural context where they live in. ${ }^{23}$

Negative attitudes towards disability also suggest a barrier which affects in three different levels:

a. In their relations with mates and other important persons.

b. In their interaction with different professionals.

c. In their interaction with other people in general. The prejudice towards these people makes them suffer rejection and this affects all aspects of their lives in a special way. ${ }^{24}$

The purpose of this study is to analyse the perceived needs and the solutions proposed by ageing people with cerebral palsy, with the aim of preventing the conditions set out by these needs and increase the personal autonomy and social inclusion.

\section{Method}

\section{Participants}

The research shows a transversal and synchronic design. A semi quantitative analysis carries out a study which describes and interprets the needs and solutions proposed by persons with cerebral palsy (from now on $\mathrm{CP}$ ) older than 45 years, their relatives and the professionals who care for them, in relation to the existence of barriers. The selection of samples is made from the Cerebral Palsy Federation of Castilla-León which is present in the regional provinces. The project is explained and the professional making the surveys are informed of its objectives. Collaboration is thanked and they guarantee the confidentiality of the data by explaining that is a research study. The surveys were done in centres or in their homes, needing approximately between 60-70 minutes. The inclusion criteria to select the sample have been: 45 year olds or older with $\mathrm{CP}$, with an ample variety according to clinical, sociodemographic and environmental variables.

The sample of $\mathrm{CP}$ persons consists of 104 persons from the Autonomy of Castilla-León, their average age is 52 and up to a cap of 72 years, with a bigger percentage of males and a clear predominance of urban dwellers. It highlights a low level of education, illiterate or neo-reader. The majority has never worked or they have worked in jobs which required low qualifications, their working status is of pensioners mainly, most of them receive a non-contributed pension. Half of CP persons live in a residential environment mainly those with a bigger degree of disability. There are many families in which the mother doesn't live, they live with one or more siblings and in the majority of these families those with CP have no children.

Next to these sociodemographic variables, clinical variables have been also evaluated. More than $50 \%$ of persons with $\mathrm{CP}$ have another disability, with the existence of a clear predominance of individuals affected by intellectual disability. Their aetiology is related mainly to perinatal and congenital factors $(96.2 \%)$, with a small range of age for acquisition of the disability oscillating between 0 years and 3 years and with medium grade of recognised disability of more than $80 \%$ $(59.6 \%)$.

The interview made in parallel to the relative's sample consists of 34 participants, they are siblings or parents who have taken part in many of the interviews. The 127 professional directives belonging to the institution sample, answered the questions in their work place, in residential homes or other centres located in towns. The surveys were answered by different professionals who work in associations assisting persons with $\mathrm{CP}$, specifically psychologists, social workers, physiotherapists and carers. They work in centres with people with physical, intellectual, hearing and visual deficiency and mental disabilities. The most represented professional categories is the social worker, followed by psychologist and physiotherapist and the services more offered which stands out is psychological help, leisure, recreation and social work.

\section{Instruments}

To evaluate the needs perceived by people with PC they have used three types of semi structured interviews: personal, relatives and institutional. ${ }^{7}$ The personal interview consists of 94 open and close questions which gather vast information about descriptive variables related to disability and also sociodemographic and environmental variables with the aim of analysing in depth the worries, needs and solutions considered appropriate. The parallel family interview has six questions to gather their opinion on the needs and demands of people with $\mathrm{CP}$ and the interview for the directives and professionals has 17 questions centred on the worries of the institution, the requests of the associated and proposed solutions.

\section{Statistical analysis}

All analyses have been made with the statistics package SPSS 21 using a 0.50 level of significance. Firstly it analyses the relation between the possible variables, age, gender, degree of disability, type of coexistence and person who takes part in the interview, with the variables which are the objective of this study, i.e. the needs and the proposed solutions. The statistic descriptors gather sociodemographic and clinical data from people of CP in Castilla-León and data about their worries, needs and solutions proposed by the persons, their relatives and the professional who assist them. 


\section{Results}

\section{Relation between variables}

When the analysis is made by means of non-parametric tests, the incidence of the variables of age, gender, degree of disability, type of coexistence and the person who takes part in the interview in relation to the variables of worry about barriers and proposed solutions, it finds that there are only significant statistical differences when gender is contrasted with the existence of barriers, i.e. males point out a higher average than women as far as the existence of barriers is concerned.

\section{Worries and perceived needs}

With regard to worries and perceived needs (Table 1) it is focused on those related to the existence of barriers as it is shared by a bigger number of people with $\mathrm{CP}$ who are getting older $(\mathrm{M}=2.20)$.

Table I Statistics on worries about the existence of barriers in people, relatives and professionals

\begin{tabular}{llll}
\hline & Persons & Families & Professionals \\
\hline $\mathrm{N}$ & 104 & 34 & 217 \\
Minimum & 0 & 0 & 0 \\
Maximum & 9 & 7 & 8 \\
Sum & 229 & 82 & 545 \\
Mean & 2.2 & 2.41 & 2.52 \\
Standard deviation & 1.913 & 1.52 & 2.555 \\
Asimetry & 1.336 & 0.894 & 0.801 \\
& 0.237 & 0.403 & 0.165 \\
Kurtosis & 1.53 & 1.195 & -0.563 \\
& 0.469 & 0.788 & 0.329 \\
\hline
\end{tabular}

With regard to worries about the existence of barriers (Table 2) when they are compared by the analysis of multiple response table, it is highlighted that people with $\mathrm{CP}$ and also their families are mainly worried by architectonic barriers; the access to transport; and social attitude. However the professionals are more worried about social barriers and acceptance by society followed by architectonic barriers.

Table 2 Percentage of worries about the existence of barriers in the interviews with persons, relatives and institutions

\begin{tabular}{llll}
\hline Existence of barriers & Persones & Families & Professionals \\
\hline Architectonic barriers & 66.6 & 59.4 & 49.3 \\
Easy access to transport & 44.9 & 43.8 & 46.1 \\
Social barriers & 33.7 & 31.3 & 55.3 \\
Accesibility to public & 29.2 & 25 & 32.2 \\
buildings & 24.7 & 28.1 & 30.9 \\
Lack of volunteers & 22.5 & 25 & 53.3 \\
Acceptance by society & 21.3 & 28.1 & 46.7 \\
Technical help & 13.5 & 12.5 & 42.1 \\
Acceptance by family & 1.1 & 3.1 & 2.6 \\
Other & 15 & 2 & 65 \\
Lost cases & 89 & 32 & 152 \\
Valid cases & 229 & 82 & 545 \\
Total responses & 172.2 & 256.3 & 358.6 \\
Total & & & \\
\hline
\end{tabular}

\section{Proposed solutions}

The solutions proposed by people with $\mathrm{CP}$ and their relatives are to deal with the basic accessibility conditions by eliminating architectonical barriers (43\% and $36.4 \%$ respectively). However the professionals focus mainly on the acceptance by the society $(29.2 \%)$ (Table 3).

Table 3 Percentage of solutions proposed in the interviews with people, relatives and institutions

\begin{tabular}{|c|c|c|c|}
\hline Proposed solutions & Persons & Families & Professionals \\
\hline $\begin{array}{l}\text { Architectonic barriers } \\
\text { elimination }\end{array}$ & 43 & 36.4 & 27.8 \\
\hline Easy access to transport & 33.3 & 36.4 & 27.8 \\
\hline Acceptance by society & 22.6 & 18.2 & 29.2 \\
\hline $\begin{array}{l}\text { More and better } \\
\text { technical help }\end{array}$ & 22.6 & 18.2 & 26.9 \\
\hline $\begin{array}{l}\text { Promotion of adapted } \\
\text { housing }\end{array}$ & 17.2 & 27.3 & 27.4 \\
\hline $\begin{array}{l}\text { Attitude change } \\
\text { programs }\end{array}$ & 15.1 & 6.1 & 23.1 \\
\hline Image campaigns & 14 & 9.1 & 19.3 \\
\hline Acceptance by family & 9.7 & 12.1 & 28.3 \\
\hline
\end{tabular}

\section{Discussion and conclusion}

The data above reflect the worry about accessibility, not only for people with $\mathrm{CP}$, but also for their families and professionals it is an important need which makes it become an obligation that must be taken on as an inspiring principle of all the programs, encouraging to be respected and achieved in every aspect of life. Urban architectonical barriers in buildings, transport and communication which prevent free and easy access to their surroundings continue to limit these people's participation, because not only worries $66.6 \%$ of participants, but also its elimination is the first solution recommended by $43 \%$.

A good part of the exclusions and discrimination suffered by people with CP comes from the persistence of the surroundings, goods, products and services which lack universal accessibility which stops or makes it very difficult for these people to exercise their normal rights. ${ }^{25}$ The majority of the actions up to now have been directed to the elimination of barriers which aims to get rid of them without promoting the design of spaces, products and services for everyone from the beginning. According to De Lorenzo, ${ }^{26}$ the reason behind the lack of coverage for basic accessibility conditions can be the heterogeneity of the present laws, the disparity of competences, the ampleness and variety of implicated services, the economic implications and the need for a deep change in the mentality of society.

When these studies are compared with the studies made by Aguado, et al. ${ }^{9}$ and Aguado, Alcedo \& Fontanil, ${ }^{27}$ about different disabilities, it is observed that in his data the existence of barriers are worries chosen in second place after worries related to personal health. However the order of choices about types of barriers is very similar highlighting the architectonic barriers.

The United Nations since the International Convention, ${ }^{28}$ includes accessibility as part of equal opportunities rights and an essential element to achieve an independent life. It proposes to get rid of obstacles in physical spaces, transport, information and communication. Equally on the global report on disability in order 
to deal with accessibility and reduce negative attitudes presents as requirements access regulations, cooperation between different sectors, an organization with a responsible leader, training in accessibility, application of universal design, participation of the interested party and citizen education. All these are measures which benefit the participation of persons with $\mathrm{CP}$ in every area. Families of people with disabilities often take up this load alone with overstrain involved in situations of close coexistence. ${ }^{29-31}$ Support and mentoring policies for the families are needed to offer a more intense response with regard to guidance, mentoring and benefits.

Talking about accessibility implies talking about usability as well, which is a term that refers to the speed and ease which people carry out their own tasks through the use of the product they are interested in. To make a product usable it is necessary to know the needs of the people who are going to use it, so that it is easy to learn, easy to use, and it gives them satisfaction, because at the end of the day it is them, not the designers who determine when a product is easy to use. In this case active participation of the interested parties is important, due to the heterogeneity of degrees and types of disability and the variety of barriers. The image of people with disabilities is changing as they are made more visible, although there is still a lot to be done by means of dissemination, information, and training which will help to reflect a positive image of active and participative people..$^{20}$

The traditional focus to eliminate barriers linked to accessibility and disability, ${ }^{32,33}$ must change towards a new idea which is extended to all the population in favour of a Design for everyone. It is about the design of product and adequate surroundings that will be used by the biggest number of people, without the need for adaptations or specialised design. This type of design benefits everyone, especially groups of people with mayor disabilities. Simple and low cost adaptations allow products or services to be used by a bigger number of people. ${ }^{34}$

Spanish legislation on accessibility is quite complete and advanced, although there are still some gaps mainly due to the lack of accessibility of products and services which have not been designed under the universal design principle. Pending challenges have to do with the compliance of the laws and seeking strategies to amend different situations renewing techniques and methods to adjust them to real needs. The difficulty of accessibility conditions social participation and the exercise of basic liberties (Education, employment, health and culture, etc.). In many occasions these difficulties are more decisive and conditioning than their own personal functional limitations, according to the National Accessibility Plan 2004-2012. ${ }^{35}$ That is why accessibility becomes an essential factor for equal opportunities and a basic criterion in activity management. There has been a lot of advances to gain the accessibility enjoyed today, however there are still some challenges to achieve and for this, efforts and improved strategies must by unified from creativity, innovation to design advantages for the whole society. Programs, working practices and procedures must include accessibility in every context, with the purpose of promoting equal opportunities and exercise people's rights regardless of their age and their abilities. ${ }^{36}$

\section{Acknowledgements}

This study has been possible thanks to the support of the Cerebral Palsy Federation of Castilla-León (Spain). Above all, thanks to the people with cerebral palsy, their families and the professional who have taken part in it. The authors would like to express our gratitude to Aguado AL \& Alcedo MA for their assistance and analytical support for this research. This study has been translated into English with the help of the students of The College of Richard Collyer.

\section{Conflict of interest}

The authors declare there is no conflict of interest.

\section{References}

1. Abellán A, Ayala A, Puyol R. Un perfil de las personas mayores en España, 2017. Indicadores estadísticos básicos. Madrid, Informes Envejecimiento en red nº 15, Spain: Springer; 2017. 48 p.

2. United Nations. Envejecimiento en el Siglo XXI: una celebración y un desafío. Londres: Help Age International: Springer; 2012.

3. Brooks JC, Strauss DJ, Shavelle RM. et al. Recent trends in cerebral palsy survival. Part II: individual survival prognosis. Developmental Medicine and Child Neurology. 2014;56(11):1065-1071.

4. Camacho A, Pallás CR, de la Cruz J, et al. Parálisis Cerebral: concepto y registros de base poblacional. Revista de Neurología. 2007;45(8):503-508.

5. Strauss DJ, Rosenbloom L, Shavelle RM, et al. Improved survival in cerebral palsy in recent decades? Dev Med Child Neurol. 2012;54(9):867-868.

6. Turk M. Health, mortality and wellness issues in adults with cerebral palsy. Dev Med Child Neurol. 2009;51(4):24-29.

7. Causapié P, Balbontín A, Porras M, et al. Libro blanco sobre envejecimiento activo. Madrid: Ministerio de Sanidad. Política Social e Igualdad; 2011.

8. World health organization. International classification of functioning, disability and health (ICF). Madrid: IMSERSO, Spain: Springer; 2001.

9. Aguado AL, Alcedo MA, Fontanil Y, et al. Discapacidad y envejecimiento: Necesidades percibidas por las personas discapacitadas mayores de 45 años y propuesta de líneas de actuación. Informe de proyecto de investigación, IMSERSO y Universidad de Oviedo: Departamento de Psicología; 2001.

10. Fernández-Ballesteros R. Envejecimiento activo. Contribuciones a la psicología. Madrid: Pirámide. Spain: Springer; 2009.

11. World health organization. World Report on Disability. Geneva, WHO: Springer; 2011.

12. Badia-Corbella M, Rodríguez-Pedraza P, Orgaz-Baz MB, et al. Calidad de vida en los pacientes con parálisis cerebral en proceso de envejecimiento. Rehabilitación. 2013;47(4):194-199.

13. Barranco MC, Bariffi FJ. La Convención Internacional sobre los Derechos de las personas con discapacidad y su potencial aplicación a las personas mayores. Madrid, Informes portal Mayores $n^{\circ}$ 105. Spain: Springer; 2010.

14. España. Ley $2 / 2013$, de Igualdad de oportunidades para las personas con discapacidad. Boletín oficial del Estado. 2013. 135 
p.

15. España. Real decreto legislativo 1/2013, por el que se aprueba el texto refundido de la ley general de derechos de las personas con discapacidad y de su inclusión social. Boletín oficial del Estado. 2013. $289 \mathrm{p}$.

16. Estrategia Europea sobre discapacidad 2010-2020. Comunicación de la comisión al parlamento Europeo, al Consejo, al Comité Económico y social Europeo y al Comité de las Regiones; 2010.

17. World health organization. Active ageing. Ginebra. OMS Springer; 2001.

18. Jones G. Ageing with cerebral palsy and other disabilities: personal reflections and recommendations. Dev med child neurol. 2009;51Suppl 4:12-15.

19. Wehmeyer ML, Abery BH. Self-determination and choice. Intellect Deve Disabil. 2013;51(5):399-411.

20. CERMI. El envejecimiento de las personas con discapacidad. Documento de posición del CERMI Estatal. Madrid: CERMI. 2012. 19 p.

21. Zamarrón MD. Envejecimiento activo: un reto individual y social, sociedad y utopía. Revista de Ciencias Sociales. 2013;21:449-463.

22. Verdugo MA, Rodríguez A, Sánchez M. Necesidades percibidas por la familia de adultos con discapacidad intelectual en fase de envejecimiento. Informe de investigación, IMSERSOe Instituto de Integración en la Comunidad (INICO). Universidad de Salamanca; 2007.

23. Fernández-Ballesteros R, Robine JM, Walker A, et al. Active Ageing :A Global Goal. current gerontology and geriatric research, special issue on active ageing. A Global Goal. 2013;ID298012:4.

24. Barriga JJ. La imagen social de las personas con discapacidad. Madrid: CERMI; 2008.

25. Jiménez A. El estado actual de la accesibilidad de las tecnologías de la información y la comunicación, TIC: observatorio fundación vodafone-CERMI, España. Madrid: Ediciones Cinca; 2011.

26. De Lorenzo R. El futuro de las personas con discapacidad en el mundo. Desarrollo humano y discapacidad. Madrid: Fundación ONCE; 2003.
27. Aguado AL, Alcedo MA, Fontanil Y. Proceso de envejecimiento en personas con discapacidad intelectual de Castilla y León: calidad de vida y necesidades percibidas. In: MA. Verdugo, et al. editors. Aplicación del paradigma de calidad de vida a la intervención con personas con discapacidad desde una perspectiva integral. Salamanca: Colección Investigación: Publicaciones del INICO; 2012. p. 95-121.

28. United Nations . Convención internacional amplia e integral para la protección y promoción de los derechos y la dignidad de las personas con discapacidad; 2006.

29. Berzosa G. Las personas con síndrome de Down y sus familias ante el proceso de envejecimiento. Madrid: Real Patronato sobre Discapacidad; 2013.

30. Madrigal A. Familias ante la parálisis cerebral. Intervención Psicosocial. 2007;16(1):55-68.

31. Navas P, Uhlmann S, Berástegui A. Envejecimiento activo y discapacidad intelectual. Madrid: Ministerio de educación, Cultura y deporte, Subdirección general de documentación y publicaciones; 2014.

32. Cayo L. Hacia unos Servicios Sociales de calidad adecuados a las necesidades de apoyo de las personas con discapacidad. Madrid. CERMI; 2012.

33. Law M, Petrenchik T, King G, et al. Perceived environmental barriers to recreational, community, and school participation for children and youth with physical disabilities. Arch Phys Med Rehabil. 2007;88(12):1636-1642.

34. Catálogo de Publicaciones de la Administración General del Estado. Accesibilidad, diseño y tecnología. Madrid: Ministerio de Sanidad, Servicios Sociales e Igualdad: Springer; 2013.

35. Plan Nacional de Accesibilidad 2004-2012. Servicios sociales, Familia y Discapacidad. Madrid: Ministerio de Trabajo y Asuntos Sociales.

36. Jönsson G, Ekholm J, Schult ML. The international classification of functioning, disability and health environmental factors as facilitators or barriers used in describing personal and social networks: a pilot study of adults with cerebral palsy. International Journal of Rehabilitation Research. 2008;31(2):119-129. 